\title{
REPRODUCTION BIOLOGY OF Capoeta trutta (Heckel, 1843) IN THE SHOUR RIVER, SOUTHWEST IRAN
}

\author{
Mehran Javaheri Baboli ${ }^{1}$, Mohsen Taghavi Niya ${ }^{2 *}$ \\ ${ }^{1}$ Department of Fisheries Science, College of Agricultural Sciences and Natural Resources, Ahvaz branch, \\ Islamic Azad University, Ahvaz, Iran \\ ${ }^{2}$ Young Researchers Club, Ahvaz Branch, Islamic Azad University, Ahvaz, Iran \\ *Corresponding Author, E-mail: M_taghavi50@yahoo.com
}

\begin{tabular}{|c|c|}
\hline ARTICLE INFO & SAŽETAK \\
\hline Received: 23 November 2013 & $\overline{\text { Reproductive characteristics of touyeni Capoeta trutta (Heckel, 1843), a }}$ \\
\hline Received in revised form: 11 July 2014 & native cyprinid in the Shour River, Iran, were investigated by monthly sam- \\
\hline Accepted: 25 August 2014 & pling between July 2010 and June 2011. Among 815 specimens captured, \\
\hline Available online: & $\begin{array}{l}\text { the overall sex ratio was } 1: 1.96 \text { (males:females). Monthly changes of the } \\
\text { gonado-somatic index (GSI) and frequency distribution of egg diameter } \\
\text { confirmed that spawning lasted from January to April. Results indicated }\end{array}$ \\
\hline Keywords: & that the age at first maturity for males is one year and for females two \\
\hline Tuwini fish & years. Fecundity increased with fish age, averages being 2591 for $1^{+}$old \\
\hline Capoeta trutta & females and 11552 eggs in mature $6^{+}$old females. Correlation of absolute \\
\hline Shour River & fecundity and body weight was high $(\mathrm{R}=0.85)$. The absolute fecundity \\
\hline Reproduction biology & between all age groups was statistically significant $(p<0.05)$. \\
\hline
\end{tabular}

\section{INTRODUCTION}

Capoeta trutta is one of the dominant fishes in the rivers of Khouzestan Province, especially in the Shour River. This subject was chosen for the present research on the one hand because of its abundance, and on the other hand because of its importance in economy and sport, and lack of studies on this species due to its specific regional distribution (Abdoli, 1999; Coad, 2008; Javaheri et al., 2012). This kind of fish has a vast distribution in the south of China, north of India, Turkmenistan, the Aral Sea, the Middle East and Anatolia (Alp, 2005).

It has 7 species and 3 subspecies in Iran (Abdoli, 1999; Coad, 2008). The Shour River is one branch of the Karun River which is an Iranian tributary of the Tigris-Euphrates basin (Afshin, 1994).

Determining the size at first sexual maturity in fish is important for population management in fisheries (Templeman, 1987) and is widely used as an indicator of minimumpermissible capture size (Lucifora et al., 1999). Knowledge about fish fecundity is essential for evaluating the potential of stock recruitment (Qasim and Qayyum, 1963). Despite the importance of this species in Iranian waters, only limited information exists on the reproductive biology of $C$. trutta in Iran (Patimar and Farzi, 2011). In light of climatic differences between the tributaries of the Tigris-Euphrates basin, we hypothesized that the populations of this species inhabiting Iranian tributaries differ from those of Turkey and Iraq in life history traits (Patimar and Farzi, 2011). Populations of this species were found in some lakes and rivers of Turkey (Polat, 1987; Unlu, 1991; Gut et al., 1996; Oymak et al., 2009; Kalkan, 2008).

The aim of this study was to report on the reproductive biology of $C$. trutta, such as the spawning season, age at sexual maturity, fecundity and egg size in the Shour River.

\section{MATERIALS AND METHODS}

A total of 815 C. trutta were captured between July 2010 and June 2011 in the Shour River. Sampling was performed by gill nets with various mesh sizes $(12 \times 12,18 \times 18,24 \times 24$ and $32 \times 32 \mathrm{~mm})$. The stations were located at latitudes $320017 / 6 \mathrm{~N}$ and longitude 490512/3 E and 320555/1N and 485904/6 E and 320543/9 N and 485911/6 E for station 1, 2 and 3, respectively.

In the laboratory, total length (TL) and total fresh weight (TW) were determined to the nearest $1.0 \mathrm{~mm}$ and $0.1 \mathrm{~g}$, respectively. After preparing the scales, age reading was carried out by microscopic examination using circular pattern and annulus number on the scales (Bagenal and Tesch, 1978; Barber and Walker, 1988; Biswas, 1993). For age determination, scales were taken from above the lateral line, below the anterior part of the dorsal fin, and age determination was carried out under a binocular microscope (Bagenal and Tesch, 1978). Sexes were determined by macroscopic observation of the gonads (Biswas, 1993). To assess the 
state of maturation, the gonado-somatic index (GSI) was calculated for each individual $(\mathrm{GSI}=$ gonad weight $/$ body weight) $\times 100$. Gonad weights were determined to the nearest $0.01 \mathrm{~g}$ and egg diameter measured to the nearest 0.01 $\mathrm{mm}$ (ocular micrometer) (Biswas, 1993). For egg counts, ovaries were preserved in modified Gilson's solution (100 $\mathrm{ml} 60 \%$ alcohol, $800 \mathrm{ml}$ water, $15 \mathrm{ml} 80 \%$ nitric acid, $18 \mathrm{ml}$ glacial acetic acid and $20 \mathrm{~g}$ mercuric chloride) for at least $48 \mathrm{~h}$. The eggs were then completely liberated from ovarian tissues by vigorous shaking. Eggs were spherical, hence diameter measurements approximate to true diameters. There are numerous ways in which to express reproductive effort in terms of egg number and egg size, and young survival (Smith and Fretwell, 1974; Abdoli et al., 2005). The total number of eggs was then weighted and random samples of about $0.1 \mathrm{~g}$ eggs were fully counted. The total number of eggs per ovary was calculated $(F=n G / g$, where $F=$ fecundity, $n=$ number of eggs in subsample, $G=$ total weight of ovaries, $g$ = weight of subsample in the same units) (Simpson, 1951; Biswas, 1993). The age at which $50 \%$ of fish were mature was considered to be the age at first maturity for both sexes (Biswas, 1993). The relationships between fecundity and fish body size and total length were tested using simple linear regressions (Biswass, 1993; Elliott, 1995). To test the null hypothesis of significant differences in the three biological variables among age classes, ANOVA and Bonferroni tests for unplanned comparison were used (Sokal and Rohalf, 1995).

\section{RESULTS}

\section{Age Distribution}

During the sampling period (July 2010 to June 2011), a total of 815 C. trutta were examined: 513 females and 261 males, while 41 specimens were immature. Two and three-year-old fish were dominant, accounting for over $70 \%$ of the total number aged, while older samples were poorly represented (Figure 1). Sex ratio of the total sample (over all seasons) was $1: 1.96$ accounting for $33.73 \%$ of males and $66.27 \%$ of females.

\section{Age at first maturity}

Captured C. trutta were checked for ovary maturity. Of the one-year-old females, $28.37 \%$ were mature, while $54.79 \%$ of one-year-old males were mature. Of the two-year-old females, $76.06 \%$ were mature, while $77.27 \%$ of two-yearold males were mature. First spawning occurred at age I for males and II for females (Table 1).

\section{Gonadal development and egg size}

Assessment of the spawning season for C. trutta in the Sour River was based on the GSI (Figures 2, 3). Ovary developments began in February and finished in April. According to the averages, the highest GSI values were determined in the samples in February (6.603) and March (8.47) in males and females. The highest and lowest mean egg diameters were $1.160 \mathrm{~mm}$ in April and $0.60 \mathrm{~mm}$ in October, respectively (Figure 4). Frequency histograms of ripe oocyte sizes showed a single spawning mode from February to April. Egg-diameter frequency distribution of ripening female Capoeta trutta in the Shour River showed a single mode (Figure 5) indicating that females laid all their eggs during the same period.

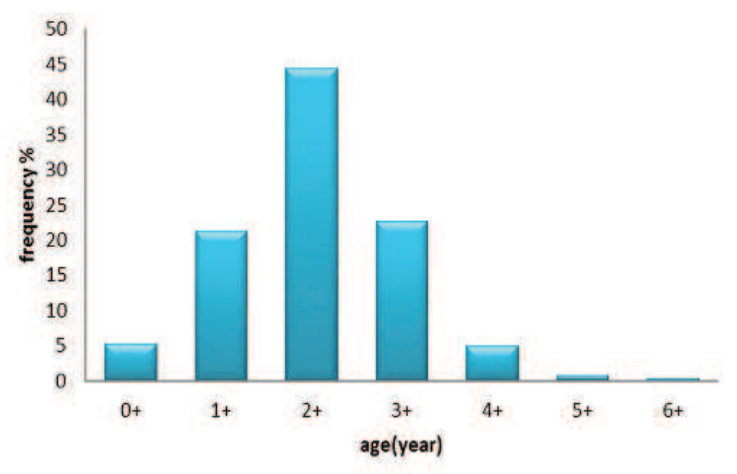

Fig 1. Age distribution of Capoeta trutta in the Shour River between July 2010 and June 2011

Table 1. Stage of maturity of female and male Capoeta trutta in relation to age, captured in the Shour River (Imm. Immature; Mat. Mature)

\begin{tabular}{lllllllll}
\hline \hline Age & $\begin{array}{l}\text { Male } \\
\text { Imm }\end{array}$ & Imm\% & Mat & Mat\% & $\begin{array}{l}\text { Female } \\
\text { Imm }\end{array}$ & Imm\% & Mat & Mat\% \\
\hline Im & 12 & 80 & 3 & 20 & 3 & 100 & 0 & 0.00 \\
I & 33 & 46.21 & 40 & 54.79 & 63 & 21.63 & 21 & 28.37 \\
II & 25 & 22.73 & 85 & 77.27 & 56 & 23.94 & 178 & 76.06 \\
III & 0 & 0 & 52 & 100 & 6 & 4.45 & 129 & 95.55 \\
IV & 0 & 0 & 8 & 100 & 0 & 0 & 29 & 100 \\
V & 0 & 0 & 0 & 0 & 0 & 0 & 0 & 2 \\
VI & 0 & 0 & 1 & 100 & 0 & 0 & 100 \\
\hline \hline
\end{tabular}




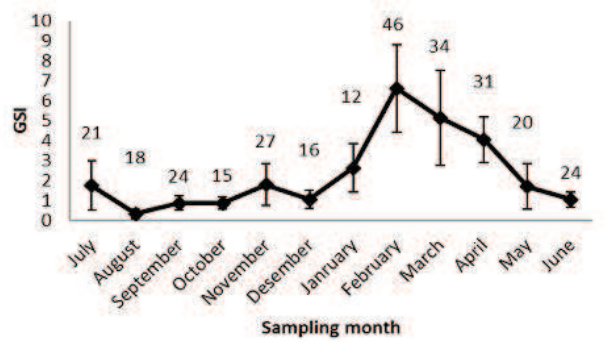

Fig 2. Seasonal fluctuations in the mean gonado-somatic indices (GSI \pm SD) in male Capoeta trutta in the Shour River between July 2010 and June 2011

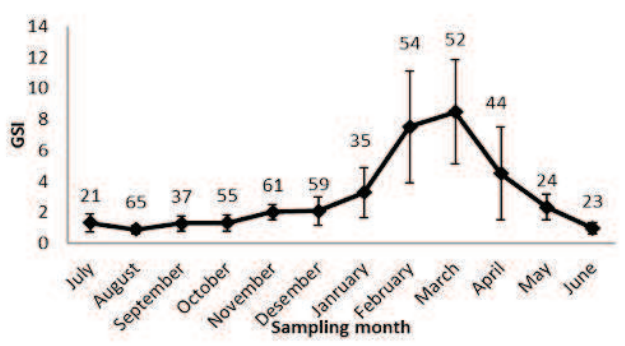

Fig 3. Seasonal fluctuations in the mean gonado-somatic indices (GSI \pm SD) in female Capoeta trutta in the Shour River between July 2010 and June 2011

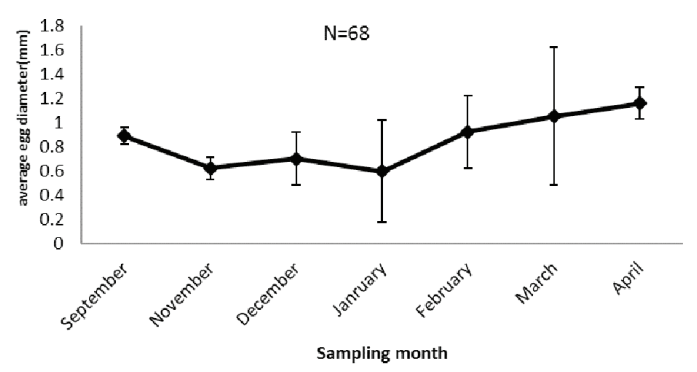

Fig 4. The (Mean $\pm \mathrm{SD}$ ) egg diameter $(\mathrm{mm})$ of Capoeta trutta in the Shour River between July 2010 and June 2011. $\mathrm{N}=$ Sample size

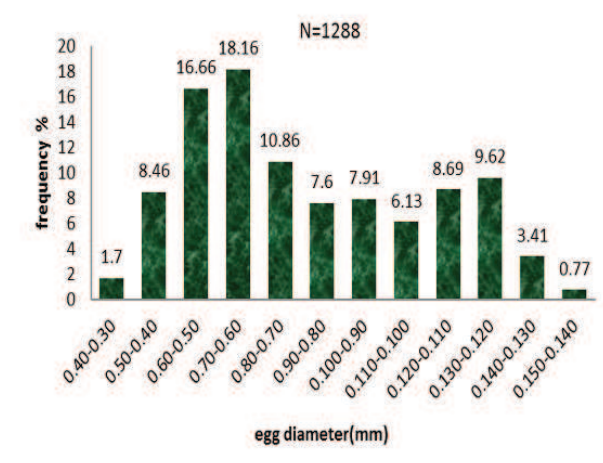

Fig 5. Egg-diameter frequency distribution of ripening female Capoeta trutta in the Shour River between July 2010 and June 2011. N=Sample size
General relationships between fecundity and total length and fecundity and body weight (Figures 6a, 6b).

Fecundity ranged from 2591 to 11552 eggs per female (Table 2) and was significantly correlated with body weight $(R=0.85)$ (Figure 6a) and total length $(R=0.59)$ (Figure 6b).
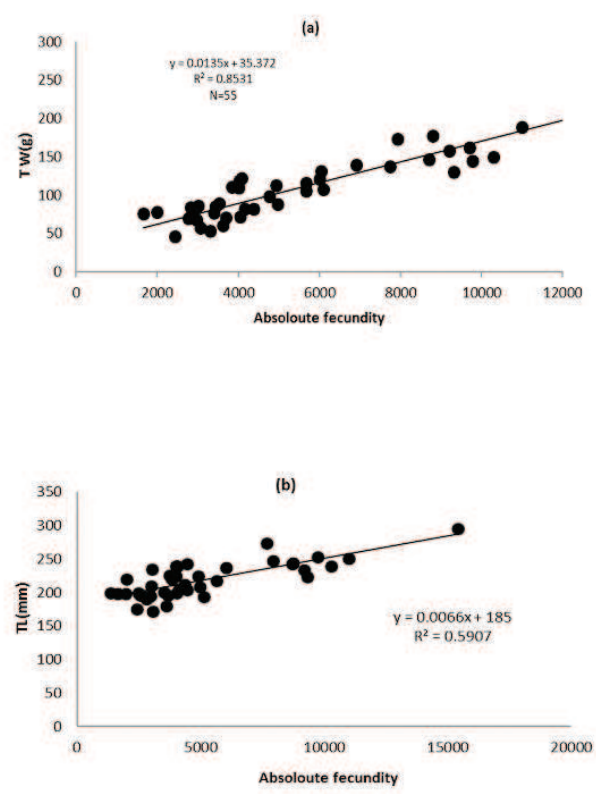

Fig 6. Relation between absolute fecundity and total length $\mathrm{b}$ and absolute fecundity and total weight a of Capoeta trutta in the Shour River between July 2010 and June 2011 (N=Sample size)

Bonferroni tests showed that mean fecundity mainly increased from age classes 1 to 3 years (from 2591 to 5067), and slightly increased among older females.

Mean egg diameter mainly increases from age classes 1 to 2 and 4 to 6 years, and slightly increases from 2 to 4 years (Table 2).

\section{DISCUSSION}

The present study is the first report on reproduction biology of C. trutta in the Shour River from southwest Iran. Previous work sampled older fish than the one available in this study and reported that $C$. trutta can grow up to 10+ in natural habitats in Turkey (Unlu, 1991; Gul et al., 1996; Polat, 1987). Nikolsky (1980) suggested that the situation in wide range of age distribution in population is accepted as an indication of sufficient level in the food of water system. The decrease in the number of individuals in old age groups in the population would cause an increase of individuals in young age groups, decreasing the food competition. 
Table 2. Bonferroni results for the test of significant differences in mean fecundity and egg diameter among age classes of Capoeta trutta from the Shour River. Mean values with the same superscript $(a-d)$ do not differ significantly $(p<0.05)$

\begin{tabular}{lccc}
\hline $\mathrm{N}$ & Age groups & $\begin{array}{c}\text { fecundity } \\
\text { S.D } \pm \text { Mean }\end{array}$ & $\begin{array}{c}\text { egg diameter } \\
(\mathrm{mm}) \\
\text { S.D } \pm \text { Mean }\end{array}$ \\
\hline 7 & +1 & ${ }^{\mathrm{a}} 570 \pm 2591$ & ${ }^{\mathrm{a}} 0.125 \pm 0.66$ \\
15 & +2 & ${ }^{\mathrm{b}} 1226 \pm 3412$ & ${ }^{\mathrm{b}} 0.159 \pm 0.72$ \\
13 & +3 & ${ }^{\mathrm{c}} 2728 \pm 5067$ & ${ }^{\mathrm{b}} 0.262 \pm 0.75$ \\
12 & +4 & ${ }^{\mathrm{d}} 2657 \pm 6002$ & ${ }^{\mathrm{b}} 0.411 \pm 0.78$ \\
5 & +5 & ${ }^{\mathrm{e}} 1909 \pm 7850$ & ${ }^{\mathrm{c}} 0.011 \pm 0.89$ \\
3 & +6 & $\mathrm{f} 5477 \pm 11552$ & ${ }^{\mathrm{d}} 0.4 \pm 0.97$ \\
\hline \hline
\end{tabular}

2009). Comparisons between our results on age-at-maturity of male and female $C$. trutta and males and females of the same species from other geographical locations and other closely-related species are also presented in Table 3. The reason for these differences is that age at first spawning is usually affected by species and such environmental factors as temperature, quantity and quality of food and water systems in which fish live (lake vs. river) (Turkman et al., 2002). The GSI of females and males peaked in March and February, respectively (Figures 3, 4). This is different from the findings for the same species in other areas (Unlu, 1991; Kalkan, 2008; Oymak et al., 2009; Patimar and Farzi, 2011). Most of them in Turkish waters reported the highest GSI values index in May. In contrast, Patimar and Farzi (2011) found the high-

Table 3. Comparison of data on age at first maturity, fork length and spawning season for various species of Capoeta species in different geographical areas

\begin{tabular}{|c|c|c|c|c|c|c|c|}
\hline Species & $\begin{array}{l}\text { Spawning } \\
\text { age year }\end{array}$ & $\begin{array}{c}\text { Sex ratio } \\
\text { M:F }\end{array}$ & $\mathrm{n}$ & $\begin{array}{l}\text { Spawning } \\
\text { period }\end{array}$ & Sex & Study area & References \\
\hline C. tinca & $\begin{array}{l}2 \\
3\end{array}$ & $1: 0.79$ & $\begin{array}{l}420 \\
234\end{array}$ & May-July & $\begin{array}{c}M \\
F\end{array}$ & Oltu Stream & (Yildirim and Arsalan, 2000) \\
\hline C. umbla & $\begin{array}{l}2 \\
4\end{array}$ & $1.25: 1$ & $\begin{array}{l}509 \\
404\end{array}$ & May-July & $\begin{array}{c}M \\
F\end{array}$ & Karasu River & (Turkman et al., 2002) \\
\hline C. trutta & $\begin{array}{l}2 \\
3\end{array}$ & $1: 1.21$ & $\begin{array}{l}228 \\
276\end{array}$ & June-July & $\begin{array}{c}M \\
F\end{array}$ & $\begin{array}{l}\text { Keban Dam } \\
\text { Lake }\end{array}$ & (Duman, 2004) \\
\hline C. trutta & $\begin{array}{l}2 \\
3\end{array}$ & $1: 0.98$ & $\begin{array}{l}106 \\
104\end{array}$ & May-June & $\begin{array}{c}M \\
F\end{array}$ & $\begin{array}{l}\text { Karakaya Dam } \\
\text { lake }\end{array}$ & (Kalkan, 2008) \\
\hline C. trutta & $\begin{array}{l}3 \\
3\end{array}$ & $1: 1.03$ & $\begin{array}{l}214 \\
208\end{array}$ & May-June & $\begin{array}{c}M \\
F\end{array}$ & $\begin{array}{l}\text { Ataturk Dam } \\
\text { Lake }\end{array}$ & (Oymak et al., 2009) \\
\hline C. c. capoeta & $\begin{array}{l}1 \\
4\end{array}$ & $1: 1.43$ & $\begin{array}{l}230 \\
415\end{array}$ & - & $\begin{array}{c}M \\
F\end{array}$ & $\begin{array}{l}\text { Kockopru } \\
\text { Dam lake }\end{array}$ & (Elp and Karabatak, 2007) \\
\hline C. damascina & & $1: 1.58$ & $\begin{array}{c}73 \\
126\end{array}$ & May & $\begin{array}{c}M \\
F\end{array}$ & Jordan River & (Stoumboudi et al., 1993) \\
\hline C. c. capoeta & $\begin{array}{l}1 \\
2\end{array}$ & $1: 1.72$ & $\begin{array}{l}158 \\
272\end{array}$ & June-July & $\begin{array}{c}M \\
F\end{array}$ & $\begin{array}{l}\text { Zerenk Dam } \\
\text { Lake }\end{array}$ & (Sen et al., 2008) \\
\hline C. c. gracillis & $\begin{array}{l}1 \\
2\end{array}$ & $1.5: 1$ & $\begin{array}{l}- \\
-\end{array}$ & May-June & $\begin{array}{c}M \\
F\end{array}$ & $\begin{array}{l}\text { Madarsoo } \\
\text { River }\end{array}$ & (Rezai et al., 2009) \\
\hline C. damascina & $\begin{array}{l}2 \\
4\end{array}$ & $2.2: 1$ & $\begin{array}{c}78 \\
171\end{array}$ & May-June & $\begin{array}{c}M \\
F\end{array}$ & $\begin{array}{l}\text { Hanna } \\
\text { Wetland }\end{array}$ & $\begin{array}{l}\text { (Soofiani and Asadollah., } \\
\text { 2010) }\end{array}$ \\
\hline C. damascina & $\begin{array}{l}2 \\
4\end{array}$ & $1: 1.57$ & $\begin{array}{l}111 \\
241\end{array}$ & May-June & $\begin{array}{c}M \\
F\end{array}$ & $\begin{array}{l}\text { Zayandeh- } \\
\text { Ruod River }\end{array}$ & (Asadollah et al., 2011) \\
\hline C. trutta & $\begin{array}{l}1 \\
2\end{array}$ & $1: 1.96$ & $\begin{array}{l}261 \\
513\end{array}$ & Feb-April & $\begin{array}{c}M \\
F\end{array}$ & Shour River & Present study \\
\hline
\end{tabular}

Results obtained from our study showed that the female/ male ratio was 1:1.96 but sex ratios in studies of Kalkan (2008) and Duman (2004) were 1: 0.98 and 1: 1.21. The sex ratio in most species is close to one but it may vary from one population of a species to another and may vary from year to year in the same population (Nikolosky, 1980). Females generally attained maturity at an older age than males, being 2+ years, at the Shour River, as opposed to C. trutta in Turkish waters (Duman, 2004; Kalkan, 2008; Oymak et al., est GSI in the Meymeh River about 1 month later than in the present study. Possible reasons for such differences might be differences in temperature regimes (Bye, 1984).

As expected, the fecundity indicated significant correlations with fish length and body weight (Figure 6a and Figure 6b). Our estimates on fecundity are lower than reported for the same species from other areas. Patimar and Farzi (2011) reported oocyte numbers in the range of 1627-18329 from the Meymeh River, and Oymak et al. (2009) showed the 
highest fecundity was 33252 eggs. It has been reported that fecundity can change in relation to fish age, length and weight, and especially temperature which is the most important ecological factor effecting the egg number. As we know, older individuals are more productive than the younger. Differences in fecundity estimates among studies might partly be an artifact due to differences in methods, or natural due to differences in fecundity with geographic location or time, or intra-specific and inter-specific differences among species (Nikolsky, 1980; Barbin and McCleave, 1997; Jonsson and Jonsson, 1999; Hossain et al., 2010).

The highest mean egg diameter was found in April (1.16 $\mathrm{mm})$ and lowest value was found in October $(0.60 \mathrm{~mm})$ (Fig. 4). The highest and lowest diameters of eggs were determined by Unlu (1991) to be $0.55-1.38 \mathrm{~mm}$, while Polat (1987) found them to be $0.43-1.03 \mathrm{~mm}$. Gul et al. (1996) reported that the highest and lowest diameter of oocyte was 0.46-1.04 mm and Kalkan (2008) found it to be 0.37-1.04 $\mathrm{mm}$. Also Oymak et al. (2009) reported that the highest and lowest egg diameter was in May $(1.69 \mathrm{~mm})$ and in August (0.42 mm), respectively.

Bonferroni tests showed that mean fecundity mainly increased from age classes 1 to 3 years (from 2591 to 5067), and slightly increased among older females. Mean egg diameter mainly increases from age classes 1 to 2 and 4 to 6 years, and slightly increases from 2 to 4 years. This relation suggests that older fish tended to have larger eggs (Dupuis and Sutton, 2011) (Table 2). This study showed that female fish spawning for the first time produce the smallest eggs. Egg diameter increases clearly between the first and second spawning.

In conclusion, this study has provided some basic information on the age at sexual maturity and fecundity of $C$. trutta that should be helpful in similar studies. Moreover, it would be useful for fisheries biologists/managers to impose adequate regulations for sustainable fishery management in the Shour River and nearby areas of the Tigris-Euphrates basin.

\section{ACKNOWLEDGEMENTS}

The authors wish to thank Dr F. Papahn, Mr Y. Mayahi and Mr R. Hakimi for their technical support, and Mr G. Bagheri for providing fish samples.

\section{Sažetak}

\section{BIOLOGIJA RAZMNOŽAVANJA VRSTE Capoe- ta trutta (Heckel, 1843) U RIJECI SHOUR, JU- GOZAPADNI IRAN}

Istraživanje reprodukcijskih osobina vrste Capoeta trutta (Heckel, 1843), izvornog ciprinida iz rijeke Shour u Iranu, vršeno je mjesečnim uzorkovanjem od srpnja 2010. do lipnja
2011.

Između 815 ulovljenih primjeraka, ukupni omjer spolova bio je 1: 1,96 (mužjaci: ženke). Mjesečne promjene gonadosomatskog indeksa (GSI) i distribucije frekvencija promjera jaja ukazuju da je mrijest trajao od siječnja do travnja.

Rezultat ukazuje da je dob prve spolne zrelosti za mužjake jedna godina, a kod ženki dvije godine. Plodnost se povećava s dobi i u prosjeku iznosi 2591 jaja za 1+ stare ženke te 11.552 jaja u zrelim ženkama kod dobi od 6+. Korelacija apsolutne plodnosti i tjelesne težine bila je visoka $(R=0,85)$. Apsolutna plodnost između svih dobnih skupina bila je statistički značajna ( $p<0,05)$.

Ključne riječi: Capoeta trutta, rijeka Shour, biologija razmnožavanja

\section{REFFRENCES}

Abdoli, A. (1999): The inland water fishes of Iran. Iranian Museum of Nature and Wildlife, Tehran. 378 pp. (In Persian with English summary).

Abdoli, A., Point, D., Sagnes, P. (2005): Influence of female age, body size and environmental conditions on annual egg production of bullhead. Journal of Fish Biology, 67, 1327-1341.

Afshin, I. (1994): Rivers of Iran. Ministry of energy Iran publication, Tehran 265 pp. (in Persian)

Alp, A., Kara, C., Buyukcapar, H. M., Bulbul, O. (2005): Age, growth and condition of Capoeta capoeta angorae (Hanko, 1924) from the upper water systems of the River Ceyhan, Turkey. Turkish Journal of Fisheries and Aquatic Sciences, 665-676.

Asadollah, S., Sofiyani, N. M., Keivany, Y., Shadkhast, M. (2011): Reproduction of Capoeta damacina (Valenciennes, 1842), a cyprinid fish in Zayandeh-Roud River, Iran. Journal of Applied Ichthyology, 27, 1061-1066.

Bagenal, T. B., Tesch, F. W. (1978): Age and growth in methods for assessment of fish production in freshwaters. IBP handbook 3. Blackwell Scientific Publications, Oxford, 101-136.

Barber, W. E., Walker, R. J. (1988): Circular spacing and annulus formation: is there more than meets the eye? The case sockeye salmon, Oncorhynchus nerka. Journal of Fish Biology, 32,237-245.

Barbin, G. P., McCleave, J. D. (1997): Fecundity of the American eel Anguilla rostrata at $45 \mathrm{~N}$ in Maine, U.S.A. Journal of Fish Biology, 51, 840-847.

Biswass, S. P. (1993): Manual of Methods in fish biology. South Asian Publishers, New Delhi. 157pp.

Bye, V. J. (1984): The role of environmental factors in the timing of reproductive cycles. In: Fish reproduction: Strategies and tactics. G. W. Potts and R. J. Wootton (Eds). Academic Press, London, 187-205.

Coad, B. (2008): The Freshwater fishes of Iran, The Canadian Museum of Nature, Ottawa. Received from personal 
website, Available from: http:// www briancoad.com

Dupuis, A.W., Sutton, T. M. (2011): Reproductive biology of female humpback whitefish Coregonus pidschian in the Chatanika River, Alaska. Journal of Applied Ichthyology, 27, 1365-1370.

Duman, E. (2004): Reproductive biology of Capoeta trutta (Heckel, 1843) Living in Keban dam Lake. F. Ü. Fen ve Mühendislik Bilimleri Dergisi. Journal of Sciences and Engineering, 16, 1, 145-150.

Elliott, J. M. (1995): Fecundity and egg density in the red for Sea trout. Journal of Fish Biology, 47, 893-901.

Elp, M., Karabatak, M. (2007): A study on C. capoeta capoeta population living in Kockopru Dam lake; Van-Turkey. Journal of Applied Biological Sciences, 1(2), 57-61.

Gul, A., Yilmaz, M., Solak, K. (1996): The growth characteristics of Capoeta trutta (Heckel, 1843) living in Tohma stream of Firat River, Turkey. Turkish Journal of Zoology, 20, 177-185.

Hossain, M. Y., Ahmed, Z. F., Islam, M. S., Jasmine, S., Ohtomi, J.(2010): Gonadostomatic index-based size at first sexual maturity and fecundity indices of the Indian River shad Gudusia chapra (Clupeidae) in the Ganges River (NW Bangladesh), 26, 550-553.

Javaheri, B. M., Taghavi, N. M., Pazira, A. (2012): Lengthweight relationship and condition factor of Capoeta trutta in Shour River downstream. Advances in Environmental Biology, 6, 1731-1734.

Jonsson, N., Jonsson, B. (1999): Trade-off between egg mass and egg number in brown trout. Journal of Fish Biology, 55, 767-783.

Kalkan, E. (2008): Growth and reproduction properties of Capoeta trutta (Heckel, 1843) in Karakaya Dam Lake. Turkish Journal of Zoology, 32, 1-10.

Lucifora, L. O., Valero, J. L., Garcia. B. (1999): Length at maturity of the green-eye spurdog shark, Squalus mitsukuii (Elasmobranchii: Squalidae) from the SW Atlantic, with comparisons with other regions. Marine and Freshwater Research, 50, 629-632.

Nikolsky, G .V. (1980): Theory of fish population Dynamics as the Biological Background for Rational Exploitation and Management of Fishery Resources, Keonigstein, Otto Keoltz Science Publishers, 323 pp.

Oymak, S. A., Davut, M., Unle, E. (2009): Reproductive Biology and histological changes in the gonads of barb, Capoeta trutta (Heckel, 1843) in Ataturk dam lake, Turkey. Turkish Journal of Fisheries and Aquatic Sciences, 23(2), 1-11.

Patimar, R., Farzi, S. (2011): Life history and other biologi- cal traits of the trout barb Capoeta trutta in the River Meymeh (Western Iran). Folia Zoologica, 60(2), 153-158. Polat, N. (1987): Age determination of Capoeta trutta (Heckle, 1843) in Keban Dam Lake. Turkish Journal of Zoology, $11,155-160$.

Qasim, S. Z., Qayyum, A. (1963): Fecundities of some freshwater fish. Proceeding of the Indian National Science Academy, 29, 373-382.

Rezai, N. M., Kamali, A., Kiabi, B., Rahmani, H. (2009): Distribution, diversity and abundance of fish species in the Madarsoo River, Golestan National Park, Iran. Iranian Journal of Fisheries, 17, 65-76.

Sen, F., Elp, M., Kankaya, E. (2008): Growth and reproduction properties of Capoeta capoeta (Guldenstaedt, 1773) in Zernek Dam Lake, Van, Turkey. Journal of Animal and Veterinary Advances, 7, 1267-1272.

Simpson, A. C. (1951): The fecundity of the plaice. Fish Invest London, 217, 3-27.

Smith, C.C., Fretwell, S.D. (1974): The optimal balance between size and number of offspring. American Naturalist, 108, 449-506.

Sokal, R., Rohlf, F. J. (1995): Biometry: The principles and practice of statistics in biological Research.3rd ed. W. H. Freeman, New York.887pp.

Soofiani, M.N. Asadollah, S. (2010): Some aspects of the growth and reproduction of Capoeta damascina (Valenciennes 1842) from the Hanna wetland, Semirum. Iranian Journal of Fisheries, 18, 145-156.

Stoumboudi, M.T., Villwock, W., Sela, J., Abraham, M. (1993): Gonadostomatic index in Barbus longiceps, Capoeta damascina and their hybrid (pisces, Cyprinidae) versus spermatozoan index in the parental males. Journal of Fish Biology, 43, 865-875.

Templeman, W. (1987): Differences in sexual maturity and related characteristics between populations of thorny skate (Raja radiate) from the northwest Atlantic. Journal of Northwest Atlantic Fishery Science, 7, 155-167.

Turkman, M., Erdogan, O., Yildirim, A., Akyurt, I. (2002): Reproduction tactics, age and growth of Capoeta capoeta umbla (Heckle, 1843) from the Askale region of the Karasu River, Turkey. Fisheries Research, 54, 317-328.

Unlu, E. (1991): A study on the biological characteristics of Capoeta trutta (Heckel, 1843) living in the Tigris River, Turkey. Turkish Journal of Zoology, 15, 22-38.

Yildirim, A., Arslan, M. (2000): Some reproduction characteristics of Capoeta tinca (Heckel, 1843) living in the Otlu Stream of Coruh Basin. Turkish Journal of Zoology, 24, 95-101. 